Meta

Journal des traducteurs

Translators' Journal

\title{
The Role of Images in the Translation of Technical and Scientific Texts
}

\section{María Isabel Tercedor-Sánchez et Francisco Abadía-Molina}

Volume 50, numéro 4, décembre 2005

Pour une traductologie proactive - Actes

For a Proactive Translatology - Proceedings

Por una traductología proactiva - Actas

URI : https://id.erudit.org/iderudit/019857ar

DOI : https://doi.org/10.7202/019857ar

Aller au sommaire du numéro

Éditeur(s)

Les Presses de l'Université de Montréal

ISSN

0026-0452 (imprimé)

1492-1421 (numérique)

Découvrir la revue

Citer cet article

Tercedor-Sánchez, M. I. \& Abadía-Molina, F. (2005). The Role of Images in the Translation of Technical and Scientific Texts. Meta, 50(4).

https://doi.org/10.7202/019857ar
Résumé de l'article

L'information véhiculée par les images dans les textes de vulgarisation scientifique prétend faciliter la compréhension des concepts et des descriptions grâce à la perception visuelle. Étant donné que le processus de conceptualisation de l'information scientifique comporte la représentation mentale des concepts et que la fonction des images est complémentaire de celle du texte, les inférences culturelles peuvent influer sur les différents aspects du traitement de l'information contenue dans les images, que ce soit leur contenu, leur forme ou leur couleur. Le processus de traduction devrait-il entraîner l'adaptation des images présentes dans le texte d'origine afin d'éviter une mauvaise compréhension du message de la part des lecteurs dans la culture d'arrivée? Cette étude fournit une description de certains aspects cognitifs et pragmatiques entourant le message virtuel transmis par les images des textes scientifiques dans le but de proposer des règles pour une analyse orientée vers la traduction.
Ce document est protégé par la loi sur le droit d'auteur. L'utilisation des services d’Érudit (y compris la reproduction) est assujettie à sa politique d'utilisation que vous pouvez consulter en ligne.

https://apropos.erudit.org/fr/usagers/politique-dutilisation/ 


\title{
The Role of Images in the Translation of Technical and Scientific Texts ${ }^{1}$
}

\author{
MARÍA ISABEL TERCEDOR-SÁNCHEZ \\ University of Granada, Granada, Spain \\ itercedo@ugr.es \\ FRANCISCO ABADÍA-MOLINA \\ University of Granada, Granada, Spain \\ fmolina@ugr.es
}

\begin{abstract}
RÉSUMÉ
L'information véhiculée par les images dans les textes de vulgarisation scientifique prétend faciliter la compréhension des concepts et des descriptions grâce à la perception visuelle. Étant donné que le processus de conceptualisation de l'information scientifique comporte la représentation mentale des concepts et que la fonction des images est complémentaire de celle du texte, les inférences culturelles peuvent influer sur les différents aspects du traitement de l'information contenue dans les images, que ce soit leur contenu, leur forme ou leur couleur. Le processus de traduction devraitil entraîner l'adaptation des images présentes dans le texte d'origine afin d'éviter une mauvaise compréhension du message de la part des lecteurs dans la culture d'arrivée? Cette étude fournit une description de certains aspects cognitifs et pragmatiques entourant le message virtuel transmis par les images des textes scientifiques dans le but de proposer des règles pour une analyse orientée vers la traduction.
\end{abstract}

\begin{abstract}
The information transmitted by images accompanying technical and scientific texts id supposed to lead to a better, visually-oriented understanding of the concepts and descriptions contained in the text. Given that conceptualising scientific information entails creating mental representations of the concepts, and since the function of images is complementary to the function of texts, cultural attitudes might well influence many aspects of an image ranging from its contents, to shape or colour. One might ask if the translation process should include the adaptation of original images in the text in order to avoid a misunderstanding of the message by readers from a target culture, or if images should be treated differently depending on the target audience.

As images in technical and scientific books and articles are often difficult to interpret a close study of them is needed so that the visual message matches the knowledge of the receiver in the target culture. In this article we propose cognitive and pragmatic criteria regarding the message transmitted by images in scientific texts as a guide to translation-oriented image analysis.
\end{abstract}

\section{MOTS-CLÉS/KEYWORDS}

images, technical and scientific texts, cognitive and pragmatic perspective, visual message

\section{Introduction}

Developments brought about by the information society demand a new approach to textual analysis prior to translation. New information formats must be considered and attention paid to "collateral information" of texts in multimedia environments. Since images are perceived before accompanying text, it is necessary to focus on the adequacy and suitability of an image in relation to the text.

As far as translation is concerned, there is a great need to explore the role of images as part of the textual frame from a cognitive as well as a pragmatic perspective. Further research is needed for the development of graphics translation/adaptation standards. In this paper, we address the 
importance of images in the context of translation as a cognitive process through the use of illustrative examples.

\section{Conceptualising and expressing information through images}

Behavioural evidence indicates that people run multi-modal simulations to perform higher cognitive tasks, such as conceptual processing and language comprehension. There is also evidence that situational contexts play a central role in construing many frames such as the meaning of a sentence (Bransford and Johnson 1973). Variables such as occlusion, size, shape, orientation, direction, and perspective affect these processes (Simmons et al 2004; Barsalou, 2003).

We take the view that just as these simulations may complement, disambiguate, or distort the sensory input, the physical image (as opposed to the mental simulation) can do the same to the textual information. As regards the importance of visualisation in translation, Kussmaul (2005: 379) states that "visualization during source text comprehension may offer a stimulus for translation."

\section{Basic level categories and prototypicality}

The importance of conceptualising a piece of information vs. perceiving it lies in the fact that conceptualisation involves inferring further information through a conceptual system, allowing the cognitive system to go beyond perceptual input (Barsalou 1999). Other authors (most notably Langacker 1983) consider perception as part of the process of conceptualisation. Since superordinate concepts are normally not easy to represent (aquatic masses, furniture), the focus of relevant conceptualisation is usually placed on the basic level categories (river, table) (Langacker 1991). Therefore, recognising an image as member of a category or as the manifestation of a concept, learning its features, being capable of reasoning around it are all important cognitive activities in the process of conceptualisation.

Prototypicality (Rosch 1978) is a concept that may be well united to that of centrality as an indicator that some members of a category may be better examples than others. According to Barsalou (1999: 582) a conceptual system supports the formulation of propositions, where a proposition results from binding a concept (type) to an individual (token) in a manner that it is true or false. If we think of an image as a manifestation of a particular concept, we can define adequacy of a particular image as the degree to which the image is a good representative of the concept it represents or, in other words, the degree to which the image remains to be central to the characteristics of the concept.

We usually expect an image to be illustrative of the most prototypical features of a concept or a text. In the following example, the image on the left is used to represent the concept "intensive agriculture". Since the information inferred by looking at the picture has more to do with the conceptual representation associated to "extensive", one may think of the image as not a very good representation of the concept it is meant to represent. On the other hand, the picture on the right is a good representative of the concept it represents, "reservoir", since it is focused on the most prototypical feature of a reservoir, ie. a dam. 

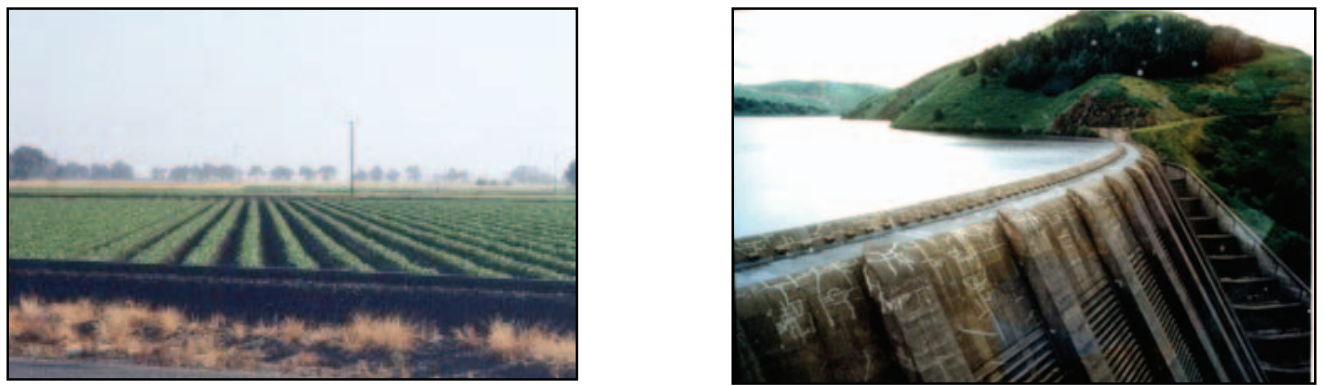

Figure 1. Examples of an inadequate image to illustrate a concept (left) and an adequate one (right) on the grounds of prototypicality.

\section{Inferring focus and function of information through image analysis}

Some images can be good instances of different concepts and texts at the same time, depending on how they are linked in the text to different contexts. The ability of a perceptual symbol to stand for a particular individual need not imply that it must represent an individual (Barsalou 1999: 584). By the same token, the same concept may be represented by different images and these representations are used in relation to the focus and function of the text they are used in. When describing a common concept such as water pollution, both of the following images may be illustrative. The choice between them may be made on the criteria of focus of information and text function. The image on the left is indeed used in the context of polluting agents, whereas the image on the right illustrates water pollution from the perspective of describing tools for waste water treatment.
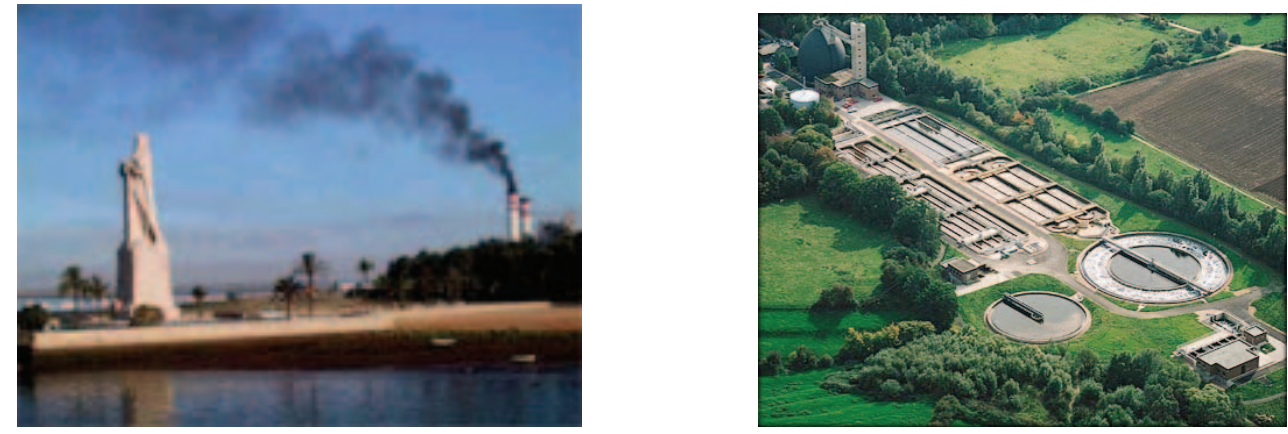

Figure 2. Two different images to illustrate the concept "water pollution".

In the context of text analysis prior to translation, it is therefore important to include image analysis as an important issue regarding the adequacy of an image in terms of catalyser of the function and focus of a particular text. Furthermore, as the eye meets the visual information before the textual one, processing information through graphic input might well condition the later understanding of the information contained in the text. As Lee-Jahnke (2005: 363) puts it for the case of mental representations: 
"In translation classes we deal mainly with symbolic information, e.g. words and icons. In order to "process" this type of information, our brain works mainly with the activation of knowledge and representations, attribution of significance and production of inferences. This leads to interpretations which, in turn, lead to actions, new knowledge and communication."

\section{Imagery in images}

Metaphoric mappings have been recognised to be central to science, not only as a means to make cryptic concepts accessible to the non-expert, but, most importantly, as a resource to conceptualise new scientific realities (Tercedor 1999; Faber and Márquez 2004; Tercedor 2005; Vandaele 2005). Since metaphor is part of our basic perceptual experience, it should also be analyzed in terms of cognitive systems and abilities (Langacker 1998: 1).

Given that acquisition and transmission of scientific concepts and processes are central for scientific/technical communication, it is not surprising that metaphoric use is present in images as well as in the text. In the following chart, the drawing used to represent the protein termed "Diablo" is illustrative of the process it represents, i.e. inducing the cell to commit suicide. However, the image cannot be extrapolated from the cellular level where it is used to the organic one, for in this context cell suicide is one of the main defences of the body against developing cancer. Thus, the metaphoric image of the protein can be said to be deceiving. This point would also illustrate the need for translators to work in close relation with the specialist, as it might be difficult to identify the nuances of meaning the metaphor transmits and modifies at an interdomain level.

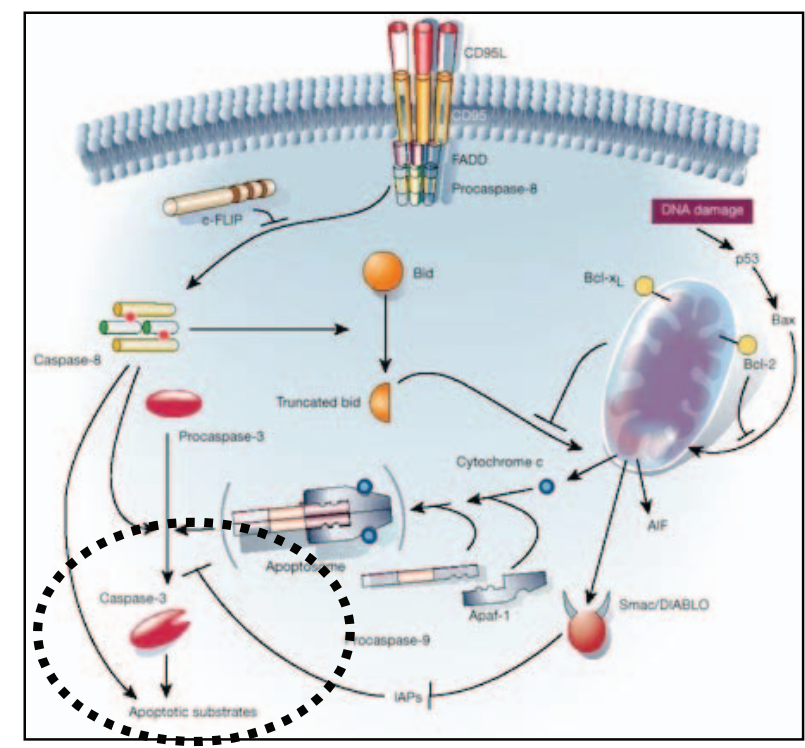

Figure 3. Chart showing the process of apoptosis. Highlighted is a metaphoric term (Smac-Diablo) which prompts to a metaphoric drawing.

Here the image has most likely developed from the mental image formed through the word Diablo. According to Langacker (2005: 381) "it is this process of forming mental images when we hear or read words that help us find a translation". In figure 3 , this process might also lead to a misinterpretation of the text by a non-expert.

\section{Criteria for choosing images in technical and scientific texts}

The following criteria should be taken into account so that the choice of images in texts will be both adequate and relevant. 
6.1. Perception and conceptualisation

Since there is evidence that situated simulation (Barsalou 2003) is a powerful interface between perception and cognition, we believe that just as the development of process-oriented terminology banks (Faber et al, in this volume) should include contextually-relevant properties of the focal category, the image should also bear a close relation to the focal categories. For example, when searching for the lexical item flood in our corpus, the word is usually accompanied by information regarding the consequences of floods for human populations. It is quite likely that the images accompanying these texts use human features to illustrate the concept, such as those in figure 4.

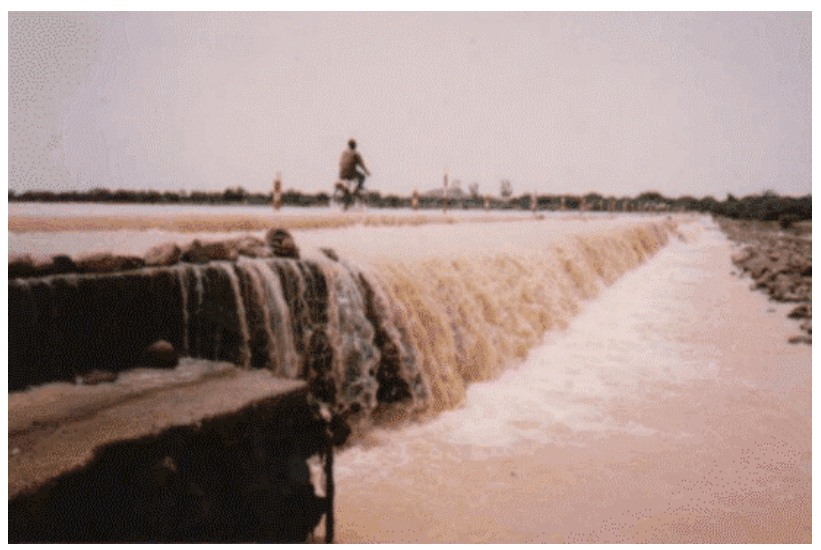

Figure 4. Image extracted from the Puertoterm image bank to illustrate the "concept flood".

Ideally, if we want to choose the image on the grounds of prototypicality and basic level categories, it should prompt a rapid identification of the concept it is associated with, correspond to a mental image, and represent the overall perceived shape. The image at the basic level will also contain most of the attributes of the category members.

\subsection{Ideology in technical and scientific texts}

There are many instances in which scientific images can pose an ideological bias. The following image inaccurately illustrates the concept water demand. The presence of an image transmitting sexual stereotypes might suggest the need to search for further bias in the textual frame.

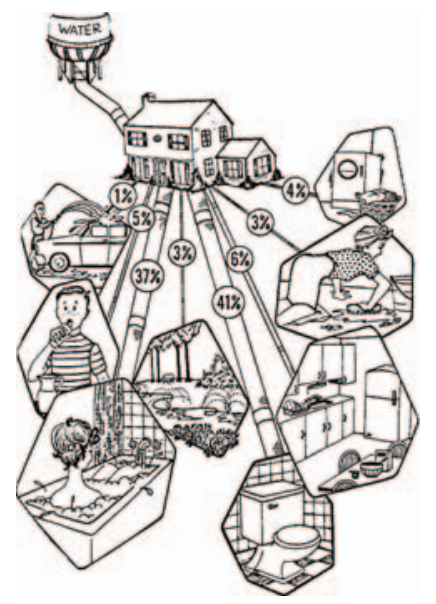

Figure 5. Image used to illustrate the concept water demand 
An interesting case is the extensive use of emoticons. In Spain, they are even used by the television channel Antena 3 TV to present information from the audio track in subtitling for the hard of hearing. However, these are not valid at an intersemiotic level. For example, the emoticon used in Japan to represent a smile is $\wedge . \wedge$. It is therefore necessary to identify potential conflict areas when presenting an image of this type.

\subsection{Textual support}

In multimedia contexts, text descriptions for images are used as a way of reinforcing visual information, and thus making the information contained in images accessible to the visually impaired, who receive the information in images through text decoders. This resource to accessibility is also useful for image retrieval as long as the following criteria are met.

The text describing the image should contain the most commonly used words (corpus frequency analysis can be used for this) and be of the minimum length necessary to describe the image, its physical features, its function or its conceptual features. In the context of teaching translation for multimedia environments, we believe that formulating text descriptions in the target text when they are absent in the source text is a sort of activity that boosts creativity and brings the student closer to real world conditions (Tercedor et al. in this volume).

\section{Conclusions}

This paper argues for the need to conduct further research into the role of graphic information in the text with a view to considering the need to adapt images in order to improve the transmission of the message to a particular audience. Different analytical criteria are explored with examples extracted from a bank of images compiled within the context of the Puertoterm research project.

\section{NOTES}

1. This paper is part of the R\&D Project Puertoterm (BFF2003-04720) funded by the Spanish Ministry of Science and Technology. Within the project, an over 20 million word corpus (English, Spanish and German) of texts on

Coastal Engineering has been compiled and a bank of images is being put together in the context of process oriented terminological work (see Faber et al. in this volume).

\section{REFERENCES}

Barsalou Lawrence, W. (1999): "Perceptual Symbol Systems”, Behavioral and Brain Sciences 22-4, p. 577660.

BARSALOU, L. W. (2003): "Situated simulation in the human conceptual system", Language and Cognitive Processes 18-5/6, p. 513-562.

BRANSFORD, J. D. and M.K. JOHNSON (1973): "Considerations of some problems of comprehension”, In W. G. Chase (Ed.): Visual information processing (p. 383-438), New York, Academic Press.

FABER, P. and C. MÁRQUEZ (2004): “The role of imagery in specialized communication”, LewandowskaTomaszczyk, B. and Alina Kwiatkowska (eds), Imagery in Language. Fertschrift in Honour of Professor Ronald W. Langacker, Peter Lang. p. 585-602.

FABer, P., MÁrquez, C and M. VegA (in this volume): "Framing Terminology: a Process-oriented Approach", Paper presented at the conference For a Proactive Translatology, Montreal, 7-9 April 2005.

KußMaul, P. (2005): “Translation through visualization”, Meta 50-2, p. 378-391.

LANGACKer, R. (1991): Concept, Image and Symbol. The Cognitive Basis of Grammar, Berlin, Mouton.

Lef-Jahnke, H. (2005): "New Cognitive Approaches in Process-Oriented Translation Training”, Meta 50-2, p. 359-377. 
Rosch, E. (1978): "Principles of Categorization" in Rosch and B. B. Lloyd (eds.), Cognition and Categorization, N. J. Erlbaum, Hillsdale.

Simmons, W. K., Hamann, S. B., Nolan, C. L., Hu, X. and L. W. BarSAlou (2004): "fMRI Evidence for the Role of Word Association and Situation Simulation in Conceptual Processing", Meeting of the Society for Cognitive Neuroscience, San Francisco, April 2004, Paper under review.

TERCEDOR SÁNCHEZ, M. I. (1999): "Rutas de metaforización y traducción especializada: una aproximación cognitiva", Sendebar 10/11, p. 249-260.

TERCEDOR SÁnCHEZ, M. I. (2004): “Esquemas metafóricos en el español de la ciencia y la tecnología”. In: Faber, P. C. Jiménez y G. Wotjak (eds.). Léxico especializado y comunicación interlingüística, Granada, Granada Lingüística, p. 233-242.

Tercedor SÁnchez, M.I., LóPez RodríGuez, C. I. and B. Robinson (2005): “Textual and visual aids for elearning translation courses", Paper presented at the conference For a Proactive Translatology, Montreal 7-9 April. VANDAELE, S. (2005): “Approche cognitive de la traduction dans les langues de spécialité : vers une systématisation de la description de la conceptualisation métaphorique”. Meta 50-2, 2005, p. 415-431. 